\title{
Türk Modernleşmesi: Reformdan Devrime (Niyazi Berkes)
}

\author{
Turkish Modernization: From Reform to Revolution (Niyazi Berkes)
}

\section{İsmail Hira*}

\begin{abstract}
Öz
III. Selim döneminden başlayarak Tanzimat, Meşrutiyet ve Cumhuriyet dönemine kadar yaşan modernleşme/batılılaşma sürecinde, Osmanlı devleti Batı karşısındaki durumunu tahkim etmeye yönelik bir takım düzenlemelere gitmiştir. Söz konusu düzenlemeler çoğu zaman dış manipülasyonların bazen de iç dinamiklere bağlı taleplerin etkisiyle gündeme gelmiştir. Yapılan bu düzenlemelerin başarı veya başarısızlıkları, Osmanlı-Türk toplum yapısına uygunluğu veya uygunsuzluğuna bağlı olarak tartışılmıştır. Bu çerçevede ortaya çıkan fikir akımlarının tartışma ve önerileri, özellikle Batı uygarlığı karşısında nasıl bir pozisyon alınması üzerinde odaklanmıştır. Bu çalışmada, Türk modernleşme sürecinde ortaya çıkan değişim planındaki pratik uygulamaların yönü ve yeterliliği konusunu tarihi, ekonomik ve sosyolojik boyutlarıyla tartışan ve kendi yaklaşımlarını teorik olarak ortaya koyan Niyazi Berkes'in sosyolojik analizleri üzerinde durulacaktır. Berkes temel yaklaşımını, Cumhuriyet dönemine kadar ortaya konmuş çözüm önerilerinin palyatif olduklarını, dolayısıyla geleneksel düzene (nizam, nizam-ı alem) eklemlenerek şekillendiği argümanı üzerinden belirlemiştir. Berkes bu yaklaşmana bağlı olarak Cumhuriyet döneminde gündeme gelen devrimci yöntem ve buna bağlı değişim programıyla gerçekçi çözümün ortaya konmuş olmasına rağmen, daha sonra devrimden sapmaları gündeme gelmesiyle Kemalist devrimin amaçlarından uzaklaşıldığını iddia etmektedir. Ona göre, geleneksel düşünce ve değerler (gericilik) toplumun gelişmesine engel olmaktadır ve bu durumdan kurtulmanın tek yolu devrimci (Kemalist) uygulamalardır.
\end{abstract}

Anahtar Kavramlar: Modernleşme, düzen, reform, devrim

\footnotetext{
* Prof. Dr., Sakarya Üniversitesi, Fen-Edebiyat Fakültesi Sosyoloji Bölümü Bu makale iThenticate sistemi tarafından taranmıştır.

Makale Gönderim Tarihi: 2 Nisan 2018
} 
İsmail Hira

\begin{abstract}
Starting from the period of Selim III, in the process of Reform, Constitutional period and republican period, Ottoman state conducted a number of regulations to fortify itself against the West. . The aforementioned regulations were brought to the agenda under the influences of mostly external manipulations and the demands coming from internal Dynamics. Success and failures of those regulations were discussed according to suitability or misfit of them to the Ottoman Turkish social structure. Discussions and suggestions of Streams of thought put forward within this framework focused on what kind of position especially against western civilization. Niyazi Berkes' sociological analysis which looks at the issues of direction and competency of practices emerged in Turkish modernisation process in terms of historical, economic and sociological dimensions will be elaborated. Berkes put forward his argument around the claim that solution offers which had been conducted up to the Republican period were palliative and thus shaped by articulating the traditional order. Berkes pointed out that although realist solutions were executed through revolutionary method and change programme in the republican period, Kemalist revolution moved away from its ideals because of the deviations which came to the agenda after the revolution. According to him, traditional thought and values hinder societal development and the only way to overcome this is revolutionary (Kemalist) practices.
\end{abstract}

Keywords: Modernisation, order, reform, revolution 


\section{Giriş}

Bir sosyolog olarak Berkes, doğal olarak toplumu, toplumsal olayları ve özellikle de Türkiye'nin son iki yüzyıllık değişim sürecini anlamaya ve yorumlamaya çalışmıştır. Berkes'in Türk toplumuna yönelik yorumları dikkate alındığında felsefe, tarih, iktisat ve sosyoloji gibi geniş bir disiplin alanını içermiş olduğu fark edilir. Bu durumda Berkes'in çok yönlü bir bilgi birikimine sahip olduğunu söyleyebiliriz. Tükiye 'de Çă̆daşlaşma, Türk Düşününde Batı Soru$n u$ ve Íktisat Tarihi, Osmanlı toplum yapısına ve söz konusu son iki yüzyıllık Türk modernleşmesi sürecine yönelik kendine özgü analizlerini içeren eserlerinin en önemlileridir.

Berkes, bir yandan incelediği dönemlerin her birinin analizini yaparken diğer yandan dönemler arasında karşılaştırmalara da yer vermektedir. Fakat sonuç itibariyle analizlerini iki temel kategoride ele alıp yorumladığını görüyoruz: Cumhuriyet öncesi dönemler ve Cumhuriyet dönemi. Her iki kategoriye tekabül eden bir takım değişimler yaşanmış olsa da, bu dönemlerin birbirinden ayrıldığı niteliksel hususiyetler vardır. İlkinde daha çok revizyonist değişim modelleri üzerinden gerçekleştirilmeye çalışılan bir takım değişim örnekleri söz konusu iken, ikincisinde ise devrimci bir model üzerinden toplumsal yapının yeni bir kültür politikası üzerinden yeniden inşa edilmesi söz konusu olduğu sonucuna varmıştır. Dolayısıyla Berkes, ancak Cumhuriyet devrimleriyle uzun yıllardan beri süregelen toplumsal sorunların nihai bir çözüme kavuşma imkânı bulduğuna iddia etmektedir.

Berkes'e göre, Tük toplumunu geçmişin geri koşullarından kurtarıp gelecekte demokratik bir toplum oluşturma çabaları olarak görülen Türkçülük, İslamcılık ve Osmanlıcılık gibi fikir akımları ve önerdikleri değişim ve çözüm yolları Türk toplum realitesiyle bağdaşmıyordu (Berkes, 1975b: 71). Bu doğrultuda yapılmaya çalışılan reform çabalarının başarısız olduklarını savunan Berkes, bunun nedeni toplumun yapısal özelliklerini ve kavrayamamalarına dayandırmaktadır.

Berkes, tarihsel süreci dikkate alarak söz konusu devrimin niteliğinin anlaşılabilmesi noktasında geniş analizler yapmaya çalışır. 
Bu süreçte ne tür engellerin bulunduğunu, bu engellere yönelik geçmişte ne türden çözüm önerilerinde bulunulduğu ve buna rağmen neden gerçekçi bir çözüme ulaşılamadığının anlaşılmasının önemli olduğuna inanır (Berkes, 1975b: 7). Çünkü Atatürk devrimlerinin anlaşılabilmesi böyle bir değerlendirmeyi gerekli kılmaktadır. Berkes, "Atatürk'ün toplumsal devrimler yoluyla çağdaşlaşmanın önkoşullarını, Türkiye'yi Doğu türü toplumlar yörüngesinden Batı türü toplumlar yörüngesine kaydırmakla yarattığını savunmuştur. Doğu türü toplumlarda toplumsal devrimler yolunun ancak böylelikle açıklanabileceğinin altını çizmiştir" (Kayal1, 2011:133).

Böylece Türk Toplumunun siyasi erki, geleneksel İslam düşüncesinden koparak, modernleşme sürecinin mümkün tek yolu olarak düşünülen bu yörünge değişimiyle yerini Batı dünyasında almayı tercih etmiş olmaktadır. Berkes'e göre, Cumhuriyet devrimlerini yürüten siyasi aklın tercihlerini dayandırdığ temel hareket noktalarından biri laikleşme diğeri de Batı uygarlığına dönme düşüncesidir (Berkes, 1985: 123). Dolayısıyla Berkes'i diğer birçok sosyologdan ayıran özelik onun bu yaklaşımına dayanmaktadır. Yani modernleşme gelenekselleştirilmiş değerlerden uzaklaşılabildiği oranda gerçekleşebilecek bir süreçtir. Cumhuriyet döneminde orta konmuş olan kültürel devrimler de bu temel önermeye dayanmaktadır. Bu gerekçeye bağlı olarak da Berkes, Cumhuriyet döneminde gerçekleştirilen Kemalist devrimleri önceki dönemlerden farklı olduğunu savunmaktadır.

Berkes, Alexander Helpland adındaki Rus asıllı bir sosyalistin Türk aydınlarına yönelik uyarılarına dikkat çekmektedir: "Siz aydınlar halktan uzaklaşmışsınız. Siz milletinizi, ya da kendi hayalinizde kahramanlık heyulası şekline sokarak göklere çıkarıyorsunuz, ya da cehalet ve muhafazacılı̆̆ından ötürü onu yerlere çalıyorsunuz. Fakat siz milletinizin kanının son damlasın akıtmakta olduğunu hala görmüyorsunuz, başkentinizin kapılar önünde gürlemekte olan top sesleri (Balkan Harbini kastediyor) kalplerinizi sarsmıyorsa, siz avcıları tarafından kuşatılmış bir av hayvanı gibi bir köşeye sıkıştırıldığınızı hala anlamıyorsanız size daha daha söyleyebilirim" (Berkes, 1975b: 70-71). Berkes, aktarmış oldu$\breve{g} u$ bu değerlendirmeden de anlaşılabileceğ gibi, Batı ile ilişkilerde belli 
bir duyarlılığa sahiptir. Modernleşme bağlamında nasıl bir yol izlenmesi gerektiğine yönünde kendine özgü bir yaklaşım ortaya koymaya çalışmaktadır.

Berkes, Batılılaşma sürecinde yetişen aydınların kendi düşünce geleneğinden koparak laik bir düşünce yapısına sahip olmaları dolayısıyla tarihlerine yabancılaştıklarına işaret eder. Diğer taraftan kendi geleceklerine devletin geleceğine bağlamışlardır. Bu aydınların reform adına yaptıkları pek çok şeyin, Avrupa devletlerinin baskılarının bir sonucu olarak oluştuğunu iddia etmektedir. Dolayısıyla bu tür reformların toplumu modernleştirmekten ziyade memleketi Batının bir uydusu haline gelmesine neden olmuştur (Kaçmazoğlu, 2012: 68). Bu bağlamda modernleşme çerçevesinde atılacak adımların, Batının çıkarına hizmet etmeyecek bir yol izlenmesi kanaatindedir. Fakat bu doğrultuda yaptığı açıklamalar, değerlendirmeler dikkate alındığında da bazı paradokslarla karşılaşmaktayız. Örneğin, Türk toplumunun sahip olduğu değerleri, yani Osmanlı tecrübesinin ortaya koymuş olduğu düşünsel ve kurumsal müktesebatı geleneksel ya da gerici unsurlar olarak görmekte, modernleşmenin önünde bir engel olarak yorumlamaktadır.

Türk toplumunun modern uygarlığa geçebilmesini gerici güçlerin etkisinin kırılmasına bağlayan Berkes, bunun için üç nokta belirlemektedir. Birincisi, Türk toplumunun yeniden biçimlenişinin 20.yy'da sürdürülebilmesi için gerici güçlerin engellerini ortadan kaldırmak. İkincisi, Bu gerici engellerden kurtulduktan sonra değgişimin hızlandırılması ve bunun için de dünyanın politik çıarlarının dışında kalmak. Son olarak da, Tük halkının yoksulluktan kurtarılabilmesi için toplumsal reformları uygulamak (Berkes, 1975b: 83). Berkes, söz konusu bu reformların, Cumhuriyet döneminde gerçekleştirilen devrimlerle hayata geçirilmeye çalışıldığını fakat kısa bir süre sonra da, bazı yöneticilerin devrimlerden sapması dolayısıyla yeni bir sürece girildiğini bir tespit olarak ortaya koyar.

\section{Berkes'in Tarihsel/Toplumsal Konulara Yaklaşımı}

Berkes, Osmanlı toplumuna yönelik sosyolojik değerlendirmele- 
rini yaparken, bazı varsayımlardan hareket ettiğini söyler. Öncelikle, daha önce benzer değerlendirmeleri yapan bazı tarihçi ve sosyal bilimcilerin, ideal bir Osmanlı tablosu çizerek tüm Osmanlı tarihini kapsayacak şekilde değerlendirmeler yaptıklarını oysa örneğin, 14. yy'dan 19. yy'a kadar geçen süre içinde toplumsal yapıda önemli değişimlerin yaşandığını göz önünde bulundurmak gerekmektedir. Bu noktada şu iki varsayımın önemine işaret ederek sosyolojik analizlerini yapmaya çalışmıştır. a) Toplumlar, ne kadar önlem alınmaya çalışılsa da, sabit değil değişmektedirler. Bir toplumsal düzen uzun süreli olarak aynı şekilde kalamaz. b) Hiçbir kural mutlak değildir; her kural kendi içinde diyalektik bir unsur taşımaktadır (Berkes,1976: 142-43). Dolayısıyla Osmanlı devlet ve toplum düzeni, ne kadar idealleştirilmiş kurallar üzerine kurulmuş olduğu iddia edilse de, kendisini dönüştürecek çelişkileri kendi yapısında taşımaktadır (Berkes,1976: 144).

Batı uygarlığında temsil edilen modern toplum düzenine geçişi tarihsel bir zorunluluk olarak niteleyen Berkes'e göre, bu zorunluluğun farkına ancak XIX. yy'ın ilk çeyreğinde varılabilmiştir. Daha önceki dönemlerde yapılmaya çalışılan düzenlemeler, daha çok savaşlardaki yenilgileri önlemeye yönelik olarak düşünülmüştü. Dolayısıyla Batı uygarlığının meydan okumalarına karşı askeri önlemlerle cevap vermeye çalış1lıyordu. Oysa Berkes bu yenilgilerin bir sonuç olup, sorunun daha derinde yattığına yani konunun zihniyetle ilgili olduğuna işaret etmekteydi. Osmanlı imparatorluğu bu haliyle bir ortaçă̆ uygarlığını ${ }^{1}$ temsil ediyordu. Bu durumda yapılması gereken şey, askeri önlemlerle sınırlı olmayıp çöküşün temel nedeni olan ekonomik zihniyetin dönüşmesiydi (Berkes, 1975b: 20-21). Bu çerçevede, Batı uygarlığı göz önünde bulundurularak yapılacak reformlar, ancak toplumun yapısal değişimiyle başarıya ulaşabilir (Berkes, 1975b: 22).

1 “Ortaçă̆ anlayışında devlet yönetimi, toplum sınıflarını oldukları yerde tutacak, toplum yapısının değişmesini önleyecek tedbirler almak demektir. $\mathrm{Bu}$ anlayışta toplumun değişmesi bozulma, anarşi sayılır. Eski Osmanlı yazarları değişime ihtilal derler, bundan kaçınılması için devlet adamlarına nasihat verirlerdi" (Berkes, 1975b: 22). 
Modernitenin muhayyilesinde bilgi pozitivizmle eş anlamlı olarak temellendirilmiştir. Osmanlı'dan Cumhuriyetin kurulması sürecine kadar yaşanan değişimler, modernitenin tahayyülünün bir ürünü olan sosyal evrimin yasalarına göre açıklanmaya çalışılmaktadır. Dolayısıyla bilgi tarihsel evrim sürecinde oluşan, nesnel ve seküler bir karakter taşımaktadır.

$\mathrm{Bu}$ bağlamda sosyolojinin işlevi, toplumsal dünyanın yasalarını keşfederek, söz konusu yasaların rehberliğinde toplumu yeniden inşa etmesidir. Böylece sosyoloji, modern toplum paradigmasının bilgisini geliştiren ve bu bilgiyi tarihsel koşullarm entelektüel ve politik arayışları için sistemleştiren bir bilim olarak görülmektedir (Yıldırım, 2012:123). Berkes de Osmanlı toplum yasına yönelik analizlerinde ve sonrasında kurulan Cumhuriyet dönemine evrilişine ait yorumlarında, yukarıda çizilen modern bilgi paradigmasına bağlı kalmıştır.

Felesefe ve bilimin ne olduğu ve neye göre tanımlanması ilişkin soruya, yine bir felsefe ve bilim anlayışından hareketle cevap verilmektedir. Bu açıdan Berkes'in, bağlı olduğu bilim geleneği dikkate alındığında, aydınlanmacı bilim anlayışının bir uzantısı veya yansıması olan modern, Avrupa-merkezci bilim geleneğinden beslendiği yani pozitivist bilim felsefesinin temel önermelerine bağlı olarak çözümlemelerini yapmaya çalıştığı görülmektedir. Berkes, toplumu ancak aydınlanmacıların önermelerine bağlı olarak gelişen bilim yoluyla anlaşılabileceğini tezine bağlıdır (Doğan, 1999: 305). Fakat burada göz önünde bulundurulması gereken husus, bilim felsefesine yönelik tek bir paradigmanın olmadığı, farklı paradigmalara bağlı olarak oluşabilen bilim anlayışları olduğu günümüzde daha da yaygın mir kanaat olarak bilinmektedir. Bu konuda Kuhn'un tartışmaları hatırlanabilir.

Dolayısıyla tarih, toplum ve kültüre ilişkin sosyal bilim yöntemlerinin çeşitlendiği ve farklı paradigmalara göre farklı yorum biçimlerinin yapılabileceği, her paradigmanın, tarihi yeniden inşa edebileceğine ilişkin bilgiler yaygınlaşmaktadır. Dolaysıyla Berkes'in topluma ve tarihe yönelik analizlerinde pozitivist, ilerlemeci, evrimci paradigmanın etkili olduğunu söyleyebiliriz. 
İsmail Hira

\section{Osmanl1/Doğu Despotizmi}

Berkes'e göre, Devlet'in toplumdan ayrı bir varlığı söz konusuydu. Toplum ise reaya olarak niteleniyordu. Devlet toplumdan ayrı bir sistemik bütünlüğü temsil ederken; toplum yapısı reâyâ ve berâyâ olarak tanımlanan bir sosyal gerçekliği yansitıyordu. $\mathrm{Bu}$ tanıma göre, reâyâ köylüleri berâyâ ise kentli halkı ifade etmekteydi. Berkes, Devlet-reâyâ ilişkisinin çoban-sürü ilişkisi üzerinden yorumlandığına işaret etmekte ve siyasetnamelerin içerdiği bilgilerin temelde bu sürüyü gütmenin usullerine işaret ettiğini dile getirmektedir (Berkes,1976: 58).

Berkes, Osmanlı devlet sisteminde her ne kadar bir devlet adaleti söz konusu ise de, bunun toplumu oluşturan unsurların (sınıfların) imtiyazsız birlikteliğini tesis etmeye matuf bir amacı gerçekleştirmekten ziyade, her bir toplumsal tabakayı bulunduğu statüde tutmaya yönelik olduğunu iddia etmektedir. Dolayısıyla adaletin yerine getirmeye çalıştığı işlev, bu statik yapıyı korumak olmuştur. Böylece Devlet, koyun sürüsü olarak nitelendirilen toplumun statik niteliğini koruyarak istikrarını sürdürmeye çalışıyordu. Dolayısıyla değiş̧im bu sistemde istenmeyen bir şeydi. Düzen/nizam esas temel amaçtı, değişim ise fesadı/bozulmayı ifade ediyordu (Berkes,1976: 60). Berkes, Osmanlı toplumunu oluşturan tabakaların (köylü, esnaf, tüccar vs) esasında sınıf olarak değerlendirilmesi gerektiğine, fakat devlet sisteminin bu unsurları sinıf olarak anlamak istemediğine işaret ederek; farklı çıarlara sahip sınıflı bir yapı arasında gerçekleşecek rekabet ve çatışmanın yol açacağı karışıklığın (fesad), söz konusu düzenin (nizam) bozulmasına neden olacağını göstermektedir (Berkes, 1976: 56-57).

Türk İktisat Tarihi adlı eserinde Osmanlı devlet ve toplum sistemini çeşitli yönleriyle inceleyen Berkes, Osmanlı Devletini despotik ${ }^{2}$

2 Berkes, Despotizm kavramının Grekçeden geldiğine işaret ederek, 'köle sahibi aile reisi' anlamına geldiğini söyler. Aristo, Doğu devletlerini köle sahibi Grek aile reislerine benzeterek onlar için 'despot' sözcügünü kullanmıştı. Daha sonra Montesquieu ve Marx tarafinda da kullanılan bu kavramı Berkes, 'ceberutluk', 'istibdat' 'tiranlık' kavramlarından ayrı tutulması gerektiğini savunur. Berkes despotizmi, Osmanlı Devleti için kullanıldığında köle sahibi olarak değil, kulluğa dayalı bir sistem olarak açıklar (Berkes, 1976: 132-135). 
bir siyasal yapıya sahip olduğunu iddia etmektedir. Bu iddianın gerekçelerini; köylü sınıfının (ve toplumu oluşturan diğer sınıfların) özgür olmamasına, çünkü özgürlüğün ancak kapitalist ekonomilerde mümkün olmasına (1976: 69), esnafın görece örgütlü oluşu tekelci devleti ürkütmesine (1976: 77), dolayasıyla devlet pençesinin esnaf üzerinde olmasina ve devlet tekelciliğinin her alana yayılmasına (1976: 78) dayandırmaktadır. Aynı şekilde despot hükümdarın, ticarette kolay ve hızlı bir şekilde servet yapma potansiyelleri nedeniyle de zanaat esnafını da tehlikeli olarak gördügünü, dolayısıyla tüccar sınıfın reayadan sayıldığına dikkat çekmektedir (1976: 79). Yine Berkes'e göre, halkın padişahlarda kutsal yetkilere sahip olduğu düşüncesi ve padişahın iradesinin her şeyin üzerinde sayılması ${ }^{3}$, despotik siyasetin özünü teşkil etmektedir (1976: 86).

Osmanlı devlet sisteminin kulluk sistemine dayanması nedeniyle devlet-toplum ayrışması söz konusudur. Devlet toplumdan kopuk bir yapıyı temsil ediyordu. Toplumu oluşturan unsurların devlet karşısında hakları ve iradesi söz konusu değildi. Devletin hizmetinde olan kullar ise, savaşlardan elde edilen esirlerden, kölelerden ve Balkanlarda fethedilen bölgelerden elde edilen devşirmelerden ${ }^{4}$ sağlanıyordu. Devlet sisteminin bu özelliği Asya ve İslam despotik devletlerinin ortak yönü olarak belirtilmiştir (Berkes, 1976: 90). Berkes'e göre, Osmanlı Devletinin despotik bir nite-

\footnotetext{
3 Berkes, Osmanlı padişahlarının sahip oldukları siyasal-yönetsel pozisyonun mutlak bir gücüne dönük boyutuna eserlerinde yer yer işaret etmektedir. Fakat padişahların mutlak gücüne yönelik verdiği bazı örneklerde aslında padişahların gücünü bazı diğer güçlerle tahkim etmesi halinde otoriter bir tutuma dönüşebildikleri görülmektedir. Örneğin, IV. Muratla ilgili verdiği bir örnekte, "IV. Murat kullara dayanarak ulemayı, ulemaya dayanak kulları, bunlara dayanarak halkı ezmeye kalkan kanlı bir terör rejimi kurdu" (Berkes, 1976: 139) kaydını düşmektedir. Bu açıklamadan padişahın mutlak bir güce sahip olmadığı da çıkartılabilir.

4 Berkes, devşirilen çocukların zorla müslümanlaştırıldı̆̆ı yönündeki Batılı iddiaların samimi olmadıklarını, bu halkların Bizans devletinin ve kilisesinin sömürücülüğü karşısında Türklere karşı gelmediklerini, Roma kilisesine düşman olan Begomiller olduğunu yazmaktadır (1976: 92).
} 
lik taşımasının önemli göstergelerinden biri de, hükümdarın $k e y f i^{5}$ bir tutuma, idareye sahip olmasıdır (Berkes, 1976: 128).

Berkes, Osmanlıyı despotik bir sistem olarak değerlendirme yönündeki Batılı sosyal bilimcilerin kavramsallaştırmalarını kullanmasının yanı sıra, onu aynı zamanda emperyalist olarak da nitelemektedir. Bu iddiasını da İran ve Mısır seferlerine dayandırmaktadır. Osmanlı tarihçilerinin Osmanl1-İran arasındaki mücadelenin nedeni olarak gösterdikleri gibi Şii-Sünni kavgası olmayıp (Berkes, 1975a: 29) Mısır seferini yapmadaki esas amaçta görüldüğü gibi altın ve Kizaldeniz ticaret yolunu kontrol altma almak (Berkes, 1975a: 30) gibi tamamen ekonomik amaçlara yönelikti. Aynı şekilde Berkes, Sultan Selim'i Hindistan'a yönelten temel motivasyonun da, altın rezervlerinin zengin bin potansiyelinin olmasına dayandırmaktadır (Berkes, 1975a: 52).

\section{Osmanlı Devlet Sisteminin İç Çelişkileri}

Berkes, devlet/toplum sistemlerinin teorik çerçevesini diyalektik düşünceye göre analiz etmeye çalışmıştır. Bu teoriye göre, her sistem kendi içinde daima kendisine karşı zıt eğilimleri barındırmaktadır. Devlet/ler güçlü zamanlarında kendilerine zıt olan eğilimleri kontrol altında tutabilmekte fakat zayıf düştüklerinde, söz konusu bu karşı unsurlar sistemi tehdit edecek boyutlara ulaşarak yeni bir sistemin oluşmasına neden olabilmektedirler. Tarih de bu diyalektik yasaya göre işlemektedir.

Osmanlı sosyo-ekonomik düzenin zamanla bozulmasıyla veya ekonomik bunalım dönemlerinde toplum katmanında giderek kendini hissettiren Âyanlar, “devlete karşı halkı, halka karşı dev-

5 “Bu sistemde 'keyfi' dediğimiz yanın teknik hukuki bir terimi vardır ki o da 'irade'dir. Halk iradesine oturtulmamış rejimlerde bir hukukun düzenlediği yan, bir de hükümdarın iradesine bırakılmış yan bulunur. Hangi rejimde olursa olsun, hukukun düzenlediği yana, devletin veya onu elinde tutanların karışması keyfilik, hatta ceberutluk olur. Sözünü ettiğimiz rejimlerde hükümdarın iradesine bırakılmış yan ne kadar geniş olursa orda keyfilik ihtimalleri o kadar fazlalaşır (1976: 129)." Berkes, keyfiliğe ilişkin yorumlarını bazen yumuşatarak, padişah iradesiyle konan kanunların tümüyle ve her zaman keyfi bir nitelik taşımadığını, fakat padişah iradesini şeriat kuralları ve devletin maslahatları tarafından sınırlanmış olduğuna işaret eder (1976: 136). 
leti temsil eder duruma geldiler" (Berkes, 1975a: 291). Bu tabaka, giderek valilik ve sadrazamlık makamı tarafından da tanınmaya başland. II. Selim, IV. Mustafa zamanında ve II. Mahmut'un ilk dönemlerinde Âyanların toplum içindeki gücü artarak yarı bağımsız bir hale gelmeye başladı. Osmanlı Devletinde aristokrasi olmadığ için söz konusu tabaka, sahip oldukları gücü iltizam tekelinden edinmiş oldukları servetten sağlıyorlardı (Berkes, 1975a: 291). 18. yy sonlarına doğru devlet, giderek Âyanlara dayanmaya başlamıştır. Oysa bu durum, Osmanlı devlet geleneğinde görülmeyen bir husustur (Berkes, 1975a: 292). Berkes'e göre, ortaya ç1kan bu tabloyu, sadece düzenin bozulmasıyla açıklamak yanlıştır. $\mathrm{Bu}$ aslında doğu toplumlarının iç çelişkilerinin doğal bir sonucu olarak değerlendirilmesi gereken bir durumdur (Berkes,1975a: 295). Dolayısıyla, Osmanlı düzenin kendi içindeki çelişkilerine bakmayarak, XVII. yüzyılda Avrupa'da başlayan devrimsel değişmelere yol açan faktörlerin Osmanlının gelişmesini önlediği yönünde açıklayamayız. Burada dikkate alınması gereken nokta sistemik bir sorun olup, sistem içindeki sömürünün, soygunculuğun, kanunsuzluğun hakim olduğu bozuk-düzenin bir sonucudur (Berkes, 1976: 140-141).

Sistemik bozuklukların neden devrime yol açmadığı sorusunu şu şekilde cevaplamamaktadır: Osmanlı toplum yapısındaki farklı çıkar grupları bozuk düzenin yıkılmasını değil devam etmesini istiyorlardı. Çünkü bu gruplar gelenekçi ve gerici bir tutuma sahiptiler. Dolayısıyla ne Osmanlı devlet adamlarının ıslahatçı tutumu ilerici olmuş ne de derebeylerinin (ulema da dahil olmak üzere) tutumu ilerici olmuştur. Bu nenenle de devrim geleneği oluşmamıştır ${ }^{6}$ (1976: 147). Çünkü devlet değişmez bir düzen üzerine kurulmuş olup, temel hedefi de söz konusu bu düzeni sürdürmektir (Berkes, 1976: 149; Berkes,1975b: 91).

\footnotetext{
6 Berkes, İbn-i Haldun'nun devlet felsefesi açısından yaptığı teorik katkıları taktir etmesine karşın, devletlerin zamanla yaşlanıp çökeceklerine ilişkin tezinin sadece doğu toplumları için geçerli olabileceğini, başka devlet sistemlerin tarihsel süreçlerini ve değişimlerini değerlendirme açısından işlevsel olmadığını iddia etmektedir (Berkes, 1976: 148).
} 
Berkes, Osmanlı sosyo-ekonomik ve politik yapısını gelenekçilik ve gericilik kavramları üzerinden analiz etmektedir. O'na göre Osmanlı Toplum Sistemi'nin, yapısı itibariyle toplumu evrimsel veya devrimsel düzeyde ileriye taşıması pek mümkün değildir. Çünkü hem sistemin kendisi hem de ona karşı olan unsurların (örneğin, celali isyanları, yeniçeri isyanları, esnaf hareketleri, nizam-i cedid reformu, sened-i ittifak) toplumsal sistemi sosyo-politik ve ekonomik bir dönüşüme uğratma rasyonalitesi yoktur. Çünkü değişim veya dönüşüm bozuluş olarak algılanmaktadır. Bu bağlamda, Nizam-ı cedit, nizam kurmaya; Tanzimat tanzim etmeye, düzene sokmaya yönelik çabalardır ${ }^{7}$. Dolayısıyla atılan adımlar değişimi sağlamaya yönelik değil, eski düzenin yeniden kuvvet bulmasına yönelik olmuştur. Berkes bu durumu bir zihniyet sorunu olarak yorumlamış ve gericilikle kavramsallaştırmıştır. O'na göre bu düşünce tarzı 19. yy sonlarına kadar sürmüştür (Berkes, 1975a: 301).

\section{Modernleşme Çabalarına Yönelik Engeller}

Berkes, Türkiye'de gerçekleştirilmeye çalışılan reformları, gericilik, emperyalizm ve yoksulluk gibi başlıklar altında ele almakta ve söz konusu reformların bu sorunların giderilmeye çalışıldığı bir süreç izlediğine işaret etmektedir (Berkes, 1975b: 38). Toplumsal değişmeye karşısında gerici akımlar sürekli direnç göstermiş ve toplumsal sorunların eski kurallara dönerek çözülebileceğini savunmuşlardır. Batılılaşma bağlamında gerçekleştirilmeye çalışılan reformların başarısızlığı ise, bu akımların iddialarını güçlendirmiştir (Berkes, 1975b: 25). Berkes gericiliği, toplumsal değişimlere karşı gelme tavrı olarak açıklamakta ve bu tür tutum ve davranışların her toplumda görülebileceğini, bunun nedeni olarak da sadece eski düzenle çıkarlarının örtüşmesinden değil bazen alışkanlıklardan da kaynaklanabileceğini göstermeye çalışmaktadır. Diğer taraftan gericilik kavramanı, sahip oldukları görüş ve düşüncelerin yaşadığı zamana uymadığının farkında olmayan kişi veya gruplar için de kullanmaktadır. Bu durumu yobazlık ola-

7 Örneğin daha sonralan (Meşrutiyet Dönemi) bu gibi kavramların yerine terakki kavramı kullanılmaya başlanacaktır. Böylece Terakki kavramı klasik toplum algısının değiştiğini sembolize etmektedir (Berkes, 1993: 144). 
rak da nitelemektedir ki, bu türün daha tehlikeli olduğuna işaret etmektedir. Berkes yobazlığı, dini temsil eden gruplar için kullandığı gibi, bu gelenekten gelmeyen, Avrupa'da eğitim görmüş aydın kesimlerini de kapsayacak şekilde genişletmektedir. Bu durumda yobazlığa varan gericiliği, toplumsal değişimin önündeki en önemli engel olarak görmektedir. Berkes'in sözünü ettiği bu karakter kendisini, çıkarlarının peşinde koşan ve kendi çıkarlarını toplumun çıkarlarına tercih eden bir tutumla göstermektedir. Örneğin toprak ağaları, derebeyleri gibi çevreler Tanzimat'a kadar yapılmak istenen reformlara engel olmak istemişlerdir. Hatta daha sonra Meşrutiyet ve Cumhuriyet dönemlerindeki reform çalışmalarının başarısızlığa uğraması yine aynı nedenden kaynaklanmıştır (Berkes, 1975b: 27).

İkinci olarak, sosyo-politik ve ekonomik ve kültürel bağlamda gerçekleştirilmeye çalışılan düzenlemeler sürecinde, Türkiye'nin kendisini Batı dünyasındaki çekişmelerden uzak tutamaması neticesinde Batılı devletlerin politik ve ekonomik bağlamda bir uydusu haline gelmesi yani emperyalizmin kıskacina yakalanması yine olumsuz bir neden olarak gösterilebilir (Berkes, 1975b: 25). Üçüncü neden olarak da, emperyalizmin söz konusu etkisiyle karşı karşıysa kalınan diş baskılar neticesinde reformlara yönelik düzenlemelerin hedefine ulaşamamış olması neticesindeki istikrarsızlığın yol açtı̆̆ı yoksullaşma, bu yöndeki çabalara karşı bir güvensizlik oluşturmuştur (Berkes, 1975b: 25).

Türkiye'nin Batı uygarlığıyla ilişkileri bu süreçte batılılaşma biçimine dönüşmüş ve batılılaşmanın temsilcisi olan ilericiler, Batılı devletlerin baskısı altında bir program takip etmişlerdir. Bu kesimin ekonomik ve diğer alanlardaki bilgi düzeyleri, söz konusu reformları yapacak nitelikte olmadığı için, çoğu zaman Batılı devletlerden destek alarak bu çabaları sürdürmek durumunda kalmaları nedeniyle de, ekonomik ve politik alanlarda birçok ödünler vermek zorunda kalmışlardır (Berkes, 1975b: 28). Bu bağlamda Türkiye'nin batılılaşma süreci dikkate alındığında, genelde Batılı devletlerin çıkarına olacak bir seyir takip ettiği görülmektedir (Berkes, 1975b: 29). 


\section{Modernleşme/Batılılaşma Çabaları Çerçevesinde Ortaya Çıkan Fikir Akımları}

III. Selim'in Osmanlı ordusunu yeniden dizayn çabalarıyla oluşan Nizam-1 Cedidin yıkılışından 1830'lu yıllara kadar geçen süre içinde, Osmanlı siyasal sisteminin yerine önerilen üç farklı model dikkati çekmektedir. Birincisi, Şeriate dayalı bir İslam devleti, ikincisi, Merkeziyetçi hükümdarlıkla taşra güçleri arasında sözleşmeye dayalı bir devlet ve son olarak da, Hükümdarın mutlak egemenliği altında merkeziyetçi bir monarşi kurmak. Fakat bütün bu tartışma ve öneriler bir siyasi model durumuna gelememiş olmakla birlikte Cumhuriyetin kuruluşuna kadar gündemde olmuştur (Berkes, Tarihsiz: 163).

Batı uygarlığına yönelik oluşan düşünce akımlarının söz konusu uygarlıkla ilgili olarak farklı değerlendirmelere sahip olmalarına karşılık, bu uygarlığın kendine özgü bir ruh, düşünce ve zihniyete sahip olarak uzun bir sosyal evrim sürecinde meydana geldiği, yine bir takım sosyal dinamiklere bağlı olarak değişimini devam ettiren bir yapıya sahip olduğu konusu tam olarak kavranamamıştır. Bu düşünce akımlarından Batıyı algılama ve temellendirme noktasında Batıyı; ırk, din, zihniyet ve teknik gibi farlı kategoriler üzerinden yorumlamaya çalışmıştır (Berkes, 1985:171).

19. yy ortalarında Avrupa uygarlığına ilişkin olarak iki husus ön plana çıkmıştı. Bunlar bireysel özgürlük ve bu özgürlükçü düşüncenin siyasal sistemi güçlü kılacağı düşüncesiydi. Tanzimatçılara göre Batı uygarlığı bireylere özgürlük getiren, devleti de güçlü k1lan bir uygarlıktı. Onlar açısından batılılaşma, söz konusu bu iki ilkenin alınmasını ifade ediyordu. Berkes'e göre, Tanzimatçıların Batı Medeniyetinin bu iki unsurunu görebilmeleri önemli olmasına karşılık, bunlara dayanarak değiştirilecek şeyin toplumun kendisi olduğunu kavrayamamışlardı. Onlara göre, bu uygarl1ğın toplumsal dönüşümlere değil, eğitim yoluyla fen ve sanayiini almak şeklinde model olarak düşünülmesi gerekliydi. Avrupa'ya gönderilen öğrenciler de bu amaca yönelikti (Berkes, 1975b: 19496). Fakat Avrupa'ya gönderilen öğrencilerden beklenen sonuç alınamamıştı. Çünkü Batının fen ve sanayisini (bilim ve teknik) almak için gönderilen öğrencilerin ilgileri başka alanlara kaymıştı. 
Örneğin Şinasi, iktisat ve maliye okumak için gönderilmesine rağmen edebiyata yönelmiş ve Sylvestre de Sacy gibi oryantalistlerle tanışarak Doğu dünyası üzerine bilgiler edinmeyi tercih etmişti (Berkes, 1975b: 198). Şinasi gibi Batıya (Fransa) giden diğer birçok öğrenci de benzer yolu izlemişdi.

Bireysel özgürlükler ve devlet sisteminin güçlü bir hale gelmesi bağlamında atılacak adımlar doğrultuşunda endüstrileşme politikaları ön plana çıkmaya başladı. Fakat sonuçta, endüstrileşme politikaları beklenen hedefleri gerçekleştiremedi. Tanzimat döneminin ilerleme ve endüstrileşme politikaları, daha çok, Devletin borçlarının artması, Hıristiyan unsurlar zenginleşirken Müslüman halkın hemen her kesiminin yoksullaşmasıyla sonuçlandı. Dolayısıyla bu gibi yenileşme/modernleşme/batılılaşma adına yapılmak istenen reformlara karşı halkta bir tepki ve endişe cumhuriyet dönemine kadar hep var olmuştur (Berkes, 1975b: 202).

Tanzimat batıcılığına karşı toplumda oluşan hoşnutsuzluklar, batılılaşma düşüncesi ve bu düşüncenin beslenmiş olduğu batı uygarlığından aktarılan çözüm önerilerinin Türk Toplumu için fayda sağlamadığı kanaatini ortaya çıkarmıştır. Yaşanan bu olumsuz gelişmeler karşısında; Batı uygarlğ̆ının ve onun toplumsal yapısıyla Türk toplum yapısının benzerlik ve farklarının neler olduğu? Batılılaşmanın faydalı ve zararl yönlerinin neler olabileceği? yönünde oluşan sorulara karşı da üç farklı eğilim/tepki ortaya çıkmıştır: Bunlardan ilki, Toplumun ilerleyebilmesi için Batı uygarlığını takip etmek ve onun izlediği ayn süreçlerin izlenmesi; ikincisi, ilkinin tam tersi bir görüşü yansıtmakta, yani söz konusu süreçlerin izlenmesine gerek olmadığı, sosyo-kültürel yapıların farklı olması nedeniyle böyle bir gereklilik de yoktur; son olarak da; ne tümüyle hiçbir sorgulamaya tabi tutmadan batı uygarlığına yönelik kurum veya çözüm yollarını almalı ne de tamamen reddetme şeklinde bir yol izlenmelidir. Sorunların çözümünde Türk toplumunun sosyokültürel kodlarını da dikkate alarak gerekli düzenlemelerin yapılması yönünde bir yol izlenmelidir (Berkes, 1975b: 202-3).

Bu üç tezin/tepkinin, topluma dair bir takım yeni düzenlemelerin yapılması gerektiği ortak nokta olarak görülmekle birlikte, bunun nasıl olacağı sorusuna yönelik gösterilen formüllerde farklılıklar 
ortaya çıkmakta ve durum bir takım anlaşmazlıklara neden olmaktaydı. Berkes, Batı uygarlığı karşısında nasıl bir tavır geliştirilmesi gerektiği tartışmalarına bağlı olarak oluşan bu üç tezin Osmanlıcılık, İslamcılık ve Avrupalılaşma/Batıcılık ${ }^{8}$ adı altında faaliyetlerini ve tepkilerini sürdürdüklerini söyler. Temelde bu üç etrafında oluşan bir takım değişik tepkiler ortaya çıkmıştır.

Berkes, Namık Kemal'i, yaşadığı dönemin en önemli düşünürü olduğunu iddia etmektedir. Bunun gerekçesini de Batıcılığa karşı biz idrakini ortaya koyabilmesine dayandırmaktadır. ${ }^{9}$ O'na göre, Namık Kemal bir Osmanlılık Milliyetçiliği geliştirerek o zamana kadar Batı karşısında, bir topluma mensubiyetini, biz duygusunu geliştirebilmeyi başaran ilk kişidir. Yine Berkes, Namık Kemal'in Batılılaşma politikalarının sonuç itibariyle Osmanlı Toplumunu ekonomik olarak olumsuz etkilediğini ve Batının bir uydusu haline getirdiğini ilk fark eden kişi olduğunu da vurgular (Berkes, 1975b: 207). Fakat Berkes'e göre, Namık Kemal'in Batı uygarlığı

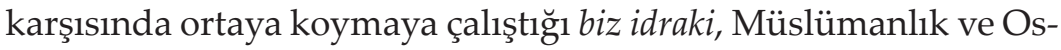
manlı devletiyle temsil edilen bir anlayışa dayanıyordu. Bizden kastı Türk ulusal toplumu değildi. Osmanlı İmparatorluğunun bağımsız bir imparatorluk olmasını istiyordu. Namık Kemal'in gerçekleşmesini istediği hedef, İmparatorluğun Avrupa devletlerinin siyasal egemenliğinden kurtulabilmesi ve bireylerin günün şartlarına uygun bir düşünce donanımına sahip olmalarıdır. Bu

8 Berkes'e göre, bu düşünce akımlan Rusya'dan gelen Türkçülük düşüncesinin etkisi altında gelişmiştir. Rusya'da Rus aydınlan arasında Batıcılar, İslavcılar, Rusçular gibi kavramsallaştırmalar kullanılmaktaydı. Aynı gelenekten gelen Rusyalı Türkçüler karşıt görüşte olanları bu formül üzerinden tanımlamışlardır (Berkes, Tarihsiz: 405).

9 Berkes, Abdülhamit zamanında Fransa'da bulunan bir Jön Türk'ün yaşadığı bir olayı anekdot olarak aktarır: Paris'te birkaç arkadaş bir kütüphanedeyken, kütüphane memuru bunlara, Siz nesiniz? diye sorunca, bunlar birbirlerine bakarak, Müslümanız demişler. Memur bu sizin dininiz, milletiniz de? Diye tekrar sorunca bu kez Osmanlıyız diye cevap vermişler. Memur, o sizin tabiiyetiniz, milletiniz nedir? diye tekrar edince cevap verememişler. Memur: bakın şuradakilere aynı soruyu sorunca onlar Ermeni ve Rum olduklarını söylediler. Jön Türk, kütüphane memurunun bu açıklaması üzerine, o zaman Türk olduğum aklıma geldi diyerek yaşamış oldukları hikâyeyi anlatır (Berkes, 1975b: 205). 
durumda İmparatorluk eski kudretine ulaşma imkânı bulabilir. Namık Kemal, Tanzimatçıların kanunlara yönelik düzenlemeler için Avrupa kanunlarını aktarma düşüncelerini de anlamsız bularak, böyle bir ihtiyacın fikıhla karşılanabileceğini iddia etmiştir (Berkes, 1975b: 212).

Namık Kemal bahsi geçen hedeflerin gerçekleşmesi için batı uygarlığını bütün kurum ve düşünceleriyle almaktan ziyade, imparatorluğun geleneksel kurumlarını (saltanat, hilafet, şeriat) muhafaza ederek bir taraftan Osmanlı birliğini yaşatmak diğer taraftan günün şartlarına uygun hürriyetlerin yeniden düzenlenmesin gerekliğine inanıyordu. Berkes, Namık Kemal'i bu açıklamalarından dolayı, Batılı toplumları ileri kılan temel toplumsal dinamiklerin gerçekliğini kavrayamamakla eleştirmekteydi. Çünkü ona göre, Namık Kemal bir taraftan Müslüman halkın kanaatkârlık zihniyetinden yakınarak Avrupa uygarlığındaki kazanma zihniyetini tasvip ederken, diğer taraftan ortaçağ İslam ahlakının üstünlüğü konusunda da bir şüphe taşımıyordu. Kalkınmanın bu düşünceler üzerinden gerçekleştirilmesi gerektiğini savunuyordu. Onun gözünde uygarlaşma, geleneksel toplum düzeninde köklü değişiklikler gerektiren bir husus olmayıp, toplumsal yapının günün şartlarına uygun olarak güncelleştirmeyi içeriyordu. ${ }^{10}$ Dolayısıyla Batı uygarlığından yararlanma Müslüman toplumun kurumsal yapısının aynı kalmasına engel değildir (Berkes, 1975b: 213). Berkes'e göre, Namık Kemal'in “Batı'yı anlamadaki eksikliklerin altında toplum görüşündeki tutuculuğun, terakki ile onun arasın-

10 Berkes, Namık Kemal'in Hürriyet'teki yazılarından hasta adamın iyileşmesine ilişkin değerlendirmesini aktarır: "Devletin hastalığının hakiki nedeni keyfi yönetim, yani halka kanuna ve hakka uymayan emirler uygulamasıdır. Osmanlı Devleti vaktiyle hürriyetin ifrat derecesine varmış bir meşruiyet hükümetiydi. Onda ulema hükmeder, padişah ve vezirler icra eder, ahali elinde silah, bu icraya nezaret ederdi. Hâlbuki şimdi kendisi kanun yapıyor, kendisi icra ediyor, bu icraatı yine kendisi kontrol ediyor. Padişahın bile otoritesi kalmamıştır. Padişah dendi mi akla Babıali, kanun dendi mi Babıali, mahkeme dendi mi Babıali, halk dendi mi yine Babıali geliyor. Şu halde: Hasta adamın iyileşmesi tabiatın iktizasına göre yaşaması için milletin eski hürriyete, şeriatın hâkimiyetinin geri getirilmesi hazımdır" (Berkes, 1985:180). 
daki çözümü bulamayışın altında toplumcu görüşün yokluğu yatar" (Berkes, 1975b: 214). Berkes açısından Namık Kemal'in Osmanlı toplumunun içinde bulunduğu olumsuzlukları, sorunları doğru tespit etmesine rağmen, çözüm noktasında ileri sürmüş olduğu önerilerin sorunların çözümüne katkı sağlayacak bir içeriğe sahip değildi.

İkinci tepki İslamcılık adı alında gelişti. İslamcı teze göre, Batı Uygarlığ1 nasıl bir Hıristiyan uygarlığ1 ise, İslam uygarlığ da kendine özgü bir uygarlıktır. Dolayısıyla izlenmesi gereken yol ne Tanzimat Batıcılığı ne de Namık Kemal ikiciliğidir. Yapılması gereken İslam Uygarlığına dönmektir. ${ }^{11}$ Çünkü Namık Kemalin alınmasını istediği ilim, fen, endüstri, bireysellik gibi konular İslam uygarlığında da mevcuttur. Ayrıca Tanzimat Batıcılarının Avrupa uygarlığına özgü olarak gösterilen bu tür nitelikler İslam Uygarlığından alınmıştır (Berkes, 1975b: 216). İslamcı düşünceye göre, Batının özü Hıristiyanlık olduğu için İslam'dan farklıdır. Dolayısıyla Batıcıların anladığı anlamda Batılılaşma İslam'ın bütün prensiplerinden vaz geçmek anlamina gelecektir (Berkes, Tarihsiz: 409). İslamcı tez açısından, şeriat İslam toplumu için bir araç olmaktan ziyade amaçtır. İçerdiği ilke ve değerler Batılı değerlerle farklıdır. Bu farklı yapısıyla hayatın tüm yönlerini kapsamakta ve şekillendirmekte olduğu için de, Batı uygarlık değerleriyle uyuşmamaktadır (Berkes, 1975b: 216).

İslamcılık Batı Uygarlığına karşı almış olduğu tavır ve tutumu, Japon modernleşmesi üzerinden örneklendirerek temellendirmeye çalışmaktadır. Oysa Berkes, Japon modernleşme modelinin İslamcı tezleri ispatlayacak bir model olmaktan uzak olduğunu iddia etmektedir. Berkes, İslamcı görüşün Japon modernleşmesi üzerinden kendi tezlerini temellendirmeye çalıştıkları ama bunun bir efsane olduğunu, gerçekte Japonların Batı uygarlığının maddi

11 Berkes'e göre, “İslamcıların anladığ 1 İslamlık Osmanlı, Türk hatta ortaçağı Müslümanlığı gibi tarihsel Müslümanlık değil, Hazreti Ömer, Hazreti Peygamber zamanına kadar götürdükleri hayali bir Müslümanlıktır. Onlarının sanısı zıddına tarihte olan Müslümanlık yaşamın her yanını kaplayan bir din olma eğilimi yüzünden daime bilime, fenne, hatta devlete aykırı olmuştur" (Berkes, 1975b: 217). 
unsurlarını alırken kendi kültürlerini koruyarak gerçekleştirdikleri bir değişim modelinin olmadığını kendi araştırma ve gözlemlerine dayanak açıklamaktadır (Berkes, 1975b: 221). Berkes, Japon modeli üzerinden kendi değişim tezlerini açıklayan İslamcıları gelenekçi ve gerici kavramları üzerinden eleştirerek gerçekte böyle bir modelin olmadığını ve dolayısıyla hayali bir Japonya ürettikleri doğrultusunda eleştirmektedir.

Berkes, Osmanlı toplumunun içinde bulunduğu şartları daha iyiye götürecek yolun Batılı değerlerin topyekûn alınıp uygulanmasıyla mümkün olabileceğin savunan Batıcı görüşü Abdullah Cevdet ve Prens Sabahattin üzerinden değerlendirmektedir. Batılılaşma düşüncesinin en aşırı ucunu temsil eden Cevdet'e göre, temel sorunun toplumda mündemiç olan hurafeler, inançlar, kanaatkârlık gibi nedenler toplumsal geriliğin temel nedenleridir ${ }^{12}$. Bu durumdan kurtulmak için mümkün olan çıkış yolu, Türk toplumunu Avrupalılarm eğitici eline vermektir. Yine Cevdet gibi batıcılar arasında, Bu toplumu biz düzenleyemeyiz, en iyisi sömürgelerde başar göstermiş İniliz ya da Fransiz valilerinden birini seçip yönetimi ona havale edelim (Berkes, 1975b: 223) şeklinde konuyu bu ölçekte dahi tartışanlar olmuştur. Cevdet'in bu Batılılaşmaya yönelik bu teklifi, kendisinin öncüsü olduğu Batıcılar tarafından bile sert bir eleştiri almıştı. Onun gözünde Batılılaşma geleneksel toplumsal yapının tamamen terkedilmesine dayandırılmıştı (Hanioğlu, 1986: 363). Dolayısıyla Batılaşabilmek için sadece teknoloji transferini yeterli görmüyor, Batı düşüncesinin de alınması gerektiği, yani Batı uygarlığını her hangi bir ayrıma tabi kılmadan bütünüyle alınmasının zorunluluğunu savunuyordu (Hanioğlu, 1986: 368).

Cevdet ayrıca, Batıdan alınması gereken diğer bir düşüncenin de biyolojik materyalizm ${ }^{13}$ olduğunu ve bu bakış açısıyla toplumsal

12 Osmanlının toplumunun geri kalmasının nedenleri üzerinde düşünen Cevdet, içtihat adlı dergisinde kaleme aldığı yazılarında konuyla ilgili şu sonuçlara varmıştır: Temel sorun, Asyalı mantalite, dejenere olan gelenekler ve devlet yapısının dine dayalı biçimidir (Berkes, Tarihsiz: 406).

13 Abdullah Cevdet'in yapmış olduğu tercümeler genellikle biyolojik materyalizm, Darwinizm gibi düşünceleri içeren metinler olmuştur. Amacı bu 
gelişmeleri açıklamanın imkânına işaret ederek, dinin toplumsal açıdan bir ihtiyaç olmadığı sonucuna varıyordu (Hanioğlu, 1986: 371). Cevdet, evrimsel süreçte kafataslarının sürekli büyüdüğünü, ilkel kavimlere göre medeni milletlerin kafataslarının daha büyük olduğu iddiasına bağlı olarak kafatası büyüklüklerinin ülkelerin gelişmişlik düzeylerine göre değiştiğini öne sürmektedir. Dolayısıyla Cevdet'e göre, bir toplumun ilerleyebilmesi ve medenileşebilmesi için o toplum içinde kafatası büyüklükleri ortalamanın üstünde olan bir grubun olması yeterlidir. Toplumların birbiriyle üstünlügü de kafatası büyüklükleri oranı belirleyecektir. Dolayısıyla toplumsal gelişme mal ve servetçe zengin olanlarla değil akıl ve zekâ olarak üstün olanların gayreti sonucunda gerçekleşecektir (Aktaran, Doğan,2006: 175). Cevdet'e göre, bu çabanın sonucunda insan beyni daha da gelişeceği için, Osmanlı aydını için gerekli olan adım, dinin hurafeleri yerine ilerlemeyi mümkün kılabilecek olan biyolojik evrim teorisinin bilinmesidir (Doğan,2006: 176).

Prens Sabahattin ise, uygarlık değişimine (terakki) balı olarak yapmış olduğu değerlendirmeleri toplumsal yapı kavramsallaştırması temelinde ele almıştır. Ona göre temel sorun, Osmanlı toplum düzenin asyatik toplum karakterine sahip olmasından kaynaklanmaktadır. Bu bağlamda sorun ancak Batılı toplum yapısına geçerek çözümlenebilir. Yani toplumcu karakterinden uzaklaşarak bireyci (teşebbüs-ü şahsi) toplum tipine ve bunun için Anglosakson eğitim anlayışına geçmek gerekmektedir. Batı uygarlığı bu özelliğinden dolayı gelişim ve kalkınmasını başarabilmiştir (Berkes, 1975b: 224).

Berkes, Bu dönemlerin ideolojileri olan Osmanlıcılık, İslamlcılık ve Milliyetçiliğin, emperyalizmin çıkarlarının bir sonucu olarak ortaya çıktıklarını, İngiliz ve Alman emperyalizmi tarafından desteklenmiş olduklarını iddia etmektedir. Ona göre, anti- emperyalist devrimciler arasında bu gerçeği anlayıp onunla mücadele eden Mustafa Kemal olmuştur (Kaçmazoğlu, 2012: 69).

düşünceler istikametinde, toplumun yeniden yapılandırılmasına katkı sağlayacak öncü/elit bir sınıf oluşturmaktı (Hanioğlu, 1986: 367; Doğan, 2006: $171 \mathrm{vd})$. 


\section{Modernleşme Siyasetinin Sonuçları: Uydulaşma}

Son iki yüz yılda yani Tanzimat'tan itibaren Batı ile olan ilişkiler dikkate alındığında, Fransa ile başlayan temaslar İngiltere ve Almanya ile devam itmiştir. Fransa o dönemde (18. yy) Avrupa'nın en güçlü ülkesi idi. Osmanlı devletinin Batı karşısında güç kaybetmesine bağlı olarak bir takım reformların yapılabilmesi bağlamında Fransa'yla politik temaslar kurulmuştu. Fransa ise verdiği desteklerden gözettiği gerçek amaç, imparatorluğun belli yerlerinin kendi ellerine geçene kadar Ruslara engel olabilmesini temin etmek içindi. ${ }^{14}$ Bundan dolayı Batının Türklere karşı diplomatik ilişkileri hep bu minval üzerinde olup hiç değişmemiştir. Alınan Batı yardımlarının ekonomik ve toplumsal kalkınmaya dönük bir katkısı da olmamıştır (Berkes, 1975b: 179). Fransa uygun bir firsatını bulduğu zamanda Osmanlı Devletinin topraklarına saldıran ilk batılı devlet olmuştur (Berkes, 1975b: 180). Benzer süreçleri daha sonra İngiltere (Berkes, 1975b: 181) ve meşrutiyet döneminde de Almanlarla (Berkes, 1975b: 183) yaşadık. Dolayısıyla Fransa ile başlayan İngiliz ve Alman devletleriyle girdiğimiz ilişkiler sonucunda onların bir uydusu olma noktasına gelmiş olduk.

Berkes'e göre, Osmanlı İmparatorluğunun 1720'den 1920'ye kadar süren iki yüzyıllık Batı politikası sonucunda toprak kayıplarının yanında aynı zamanda Batılı ülkelerinin uydusu haline gelmesi durumundan ancak Ulusal Kurtuluş Savaşıyla çıkılabilmiştir. Berkes, Ulusal Kurtuluş Savaşı'yla batıya dönük politikaların ve batı algısının yeni bir evreye girdiğini iddia etmektedir. Bu yeni evrenin temel argümanı, Türkiye ancak Batıya rağmen Batılılaşabileceği veya Batıdan bağımsız olmayan hiçbir ülkenin Batılılaşamayacağıdır (Berkes, 1975b: 186). Bu bağlamda Batıya dönük algı, "Hıristiyan dünyası olarak Batı, Avrupa Devleti olarak Batı, emperyalizm olarak Batı anlayışından sonra Çă̆daş uygarlık olarak Bati' biçimine dönüşmüştür. Çağdaş uygarlık olarak beliren bu algı,

14 Berkes'e göre, "İşin ters bir yanı da, Fransız diplomasisinin gerçek amacının bu olduğunu Batıcılardan ziyade gericilerin görebilmiş olması, bunun etkisi altında Batılılaşmaya şiddetle karşı gelmeleri, reformcuların gâvurlara satılmış kişiler olduğunu halk arasında yaymaları oldu" (Berkes, 1975b: 179). 
Batıcılığı değil, toplumsal yapının devrimci bir perspektifle dönüştürülmesini temsil etmektedir (Berkes, 1975b: 187). Batı, 18. yy'a kadar kendini din (Hıristiyanlık) üzerinden, sonrasında ise, uygarlık kavramıyla tanımlamaya başlamıştır. Dolayısıyla Batının bilim ve teknolojik değerler ve seküler bir temel üzerinden kendini inşa etmeye çalışması, temsil ettiği ve alınması gereken şeyin dine veya kültüre ait değerler değil, uygarlı̆̆a biçimini veren bilim ve teknik olduğu yönünde bir düşüncenin oluşmasına neden olmuştur.

\section{Cumhuriyet Devrimleri ve Modernleşme}

Berkes, III. Selim'den başlayarak Cumhuriyet dönemine gelinene kadar farklı dönemlerde gerçekleştirilmeye çalışılan yenileşme projelerini/hareketlerini, Cumhuriyet döneminde gerçekleştirilmeye çalışılan modernleşme projelerinden ayrı tutar. Ona göre, Cumhuriyet dönemi öncesine tekabül eden yenileşme/modernleşe faaliyetleri, toplumu yeni bir evreye taşımaktan ziyade, ideal olarak görülen eski düzenin (nizam) yeniden güçlenmesine katkı sağlayacak girişimlerdir. Dolayısıyla bu tür girişimler "ortaçă̆ düzenini bırakıp yeni bir toplum düzenine geçmek anlamına gelmiyordu" (Berkes, 1975b: 91). Ayrıca Tanzimat ve Meşrutiyet dönemlerinin aydınlarının Osmanlı İmparatorluğunu Batı karşısındaki konumunu daha güçlü kılmaya ve sonrasında kalkınmaya yönelik öne sürmüş oldukları çözüm önerileri ve bunlara bağlı uygulamalar beklentileri karşılayamamıştır (Berkes, 1975b: 72).

Berkes, Meşrutiyet (Abdülhamit) dönemi ile Cumhuriyet dönemi arasındaki farklılıkları inkılap (devrim) ve hürriyet (özgürlük) kavramları üzerinden açıklamaya çalışmaktadır. Ona göre Abdülhamit'in baskılarına karşı aydınların özgürlüğü bayraklaştırmalarına karşın, 1908'den sonda oluşan özgürlük rejimi doğrultusunda deorim kavramı ön plana çıkmış ve bu çerçevede toplumsal ${ }^{15}$ alanda yapılacak değişmeler konu edinilmiştir. Devrim kavramındın önce daha çok ihtilal, inkılap kavramları kullanılıyor-

15 "O zamandan sonra eski içtimaat-ı insaniye, camia-i beşeriye gibi komik terimlerin yerine düpedüz toplum (cemiyet) terimi kullanılmaya başlandı" (Berkes, 1975b: 225). 
du. İhtilal, darbeyle yapılan hükümet değiş̧ikliği, inkılap ise, toplumsal alanda gerçekleştirilen değişiklikleri ifade ediyordu. Cumhuriyet dönemiyle devrim kavramı daha popüler hale gelmiştir. Fakat Türk toplumunda Batılı toplumlarda olduğu gibi toplumsal değişimlerin lokomotifi sınıf çatışmaları değil, devlet organıdır. Dolayısıyla devrim kavramından toplumun sosyo-politik bir dönüşüme uğramasından ziyade, bir uygarlıktan başka bir uygarlığa geçiş olarak anlaşılmış ve toplum bu çerçevede değiştirilmek ${ }^{16}$ istenmiştir (Berkes, 1975b: 225-27).

Cumhuriyeti devrimle özdeşleştiren Berkes, Cumhuriyet döneminde yapılan tüm değişim faaliyetlerini Tanzimat ve Meşrutiyet dönemlerindeki düzenlemelerden çok farklı bulmakta, yapılmak istenen değişimlerin gerçek mecrasını bu dönemde bulduğunu ve bunun gerekçesini de Cumhuriyetin devrimci karakterine bağlamaktadır. Ona göre, devlet ne kadar toplum sınıflarından bağımsızlaşırsa devrimcilik şansı o kadar artar; ne kadar sınıfların etkisi altında olursa bu şans o ölçüde azalır... Devlet halkın iradesine dayanmadığı ölçüde devrimci olma şansı artar; hürriyetçi ve demokratik olduğu zamanlarda ise bu şans azalır ${ }^{17}$ (Berkes, 1975b: 228).

Berkes, Cumhuriyet döneminde gerçekleştirilmeye çalışılan kültürel değişiklikleri toplumsal devrimlerin temelini oluşturması açısından önemli ve zorunlu olarak görmektedir. Ayrıca söz konusu bu kültürel devrimlerle Cumhuriyet ideolojini oluşturarak, yeni bir toplum inşasına gidilmiştir (Kayalı, 2011:121). Bu deği-

16 Abdülhamit'in endişe duyduğu kesim, Batıcı aydın, subay ve siyaset adamlarıydı. Cumhuriyet döneminde ise geniş halk kitleleriydi (Berkes, 1975b: 227). Siyaset/Devlet-Aydın/halk arasında yaşanagelen gerilimler bu çerçevede yorumlanabilir.

17 Bu tür değerlendirmeler Tanzimat'tan beri Türk aydının temel bir paradoksudur. Kendi düşünce ve istekleri doğrultusundaki gelişmelerin, halktan destek bulup bulmaması çok önemli bulunmazken, tasvip itmedikleri bir durumla karşılaştıklarında halk ön plana çıkartılarak, onun üzerinden muhalif bir siyasal söylem geliştirmek istemişlerdir. Dolayısıyla Batı uygarlığına geçmek için halka müracaat etmek anlamsızdır. Çünkü halkın gündeminde böyle bir şey söz konusu değildir. Bundan dolayı devrimler genelde tependen inmeci bir yöntemle gerçekleştirilmeye çalışılmıştır. 
şimlerle Cumhuriyet döneminden önceki reform hareketlerinden farklı bir yol (devrim) izleyerek, sosyal, kültürel ve politik çerçevede yeni bir rejimin ortaya çıması sağlanmış oluyordu.

Cumhuriyet döneminde yenileşme yönündeki çabalar üç noktada öncekilerden ayrılmaktadır. Illk olarak, halkçılık ve ulusal bağımsızlık temelinde, saltanat (Osmanlıcılık), hilafet (İslamcılık) ve Turancılık gibi düşünce hareketlerinin etkisiz hale getirilerek, düşünülen yenilikler için uygun bir alan açlmıştır. İkincisi, söz konusu devrimlerin önemli bir özelliği, siyasal sistemin dönüştürülerek din-devlet ayrımına dayanan Cumhuriyet rejimine geçilmesinin sağlanmış olmasıdır. Bu nokta, Cumhuriyetin devrimci karakterini temsil etmektedir. Son olarak da, devrim sürecinde, gerçekleştirilmek istenen toplumsal değişimin ve kalkınma hamlelerinin önünde birer engel olarak görülen geleneksel kurumlar, adetler, alışkanlıklar ve kanunların kaldırılması ve bunların yerine, batıdan alınan kurum, değer ve kanunların ikame edilmesidir (Berkes, 1975b: 89; Berkes, 1993: 151).

Berkes, Cumhuriyet devrimleri bağlamında gerçekleştirilmek istenen modernleşme bağlamındaki dönüşümleri, dar anlamda dindevlet ayrımı üzerinden yorumlamanın yetersizliğine işaret ederek, esasında meselenin daha geniş bir çerçeveden ele alınması gerektiğini öne sürmektedir. Dolayısıyla konu kurumsal ayrışmalardan ziyade, kutsallaştırılmış gelenek boyunduruğundan kurtulma sorunu olarak değerlendirilmektedir. Bu bağlamda laiklik, bu tür geleneklerden kopuşun doğal bir sonucu olarak oluşur (Berkes, Tarihsiz: 17). Modernleşme süreçlerini daha çok çağdaşlaşma olarak tercih eden Berkes, çağdaşlaşmayı, kutsal olarak görülen alanın ekonomik, teknolojik, siyasal, eğitsel, cinsel bilgisel yaşam alanlarının daralmasl, etkisizleşmesi sorunu olarak yorumlamaktadır. Buna karşı olan çevreleri de gerici olarak kavramsallaştırmaktadır (Berkes, Tarihsiz: 21).

Berkes gericiliği, III. Selim'den itibaren Türk toplumunda yapılan yenileşme/modernleşme çabalarının önünde bir engel olarak görmektedir. Cumhuriyet dönemindeki devrimlerin hedefinden saptırılması ve dolayısıyla da yine gerici güçlerin müdahaleleriyle sonuçlanmıştır. Örneğin, Eğitim alanında yapılan reformlardan 
olan Köy Enstitüleri projesi belli bir süre sonra söz konusu bu gerici güçlerin etkisiyle akamete uğramıştır (Berkes, 1975b: 130). Fakat ona göre burada temel problem toplumsal kesimlere devrimlerin anlatılamamasından kaynaklanmaktadır. Devlet eliyle toplumu aydınlatma girişimi toplumun sembollerine yönelince bu durum ters tepki yaratmıştır (Berkes, 1975b: 130).

Berkes Türk toplumunun modernleşmesinin önünde, gerici olarak kavramsallaştırdığ İslamcı, Osmanlıcı ve Turanc $1^{18}$ ideolojileri ve bunları destekleyen geniş halk kitlelerini görmüştür. Liberal ve sosyalist ideolojileri ise çağdaş uygarlığa geçişin temel lokomotifi olarak düşünmüştür. Dolayısıyla liberal ve sosyalist ideolojiler, Berkes açısından medeniyet değişimini ve toplumsal kalkınmayı sağlayacak bir imkân olarak görülürken, diğer söz konusu ideolojiler ise, uygarlaşmanın önündeki ciddi birer engel olduğu şeklinde yorumlanmıştır. Aynı zamanda ilerici ideolojilerin halk nezdinde fazla bir desteğinin olmaması, toplumsal reformlar için ordunun işlevini ön plana çıkarmıştır (Berkes, 1975b: 88).

\section{Cumhuriyet Devrimlerinin Nitelikleri}

Cumhuriyet döneminde gerçekleştirilmeye çalışılan devrimler Tanzimat ve Meşrutiyet dönemlerindeki reformlardan nitelikleri yönüyle farklılık göstermiştir. Bu noktada ortaya çıkan en bariz fark, geleneksel Osmanlı-İslam temeli üzerine oturan toplumsal yapının ulus temeli üzerine oturtulma çabasıdır. Bu bir paradigma dönüşümüdür ki, bunun başarılmasıyla batılılaşma bir amaç olmaktan ziyade toplumsal yapının doğal yörüngesine oturmuşluğunu yansıtacaktır. Türk toplumunun uygarlık yörüngesine girebilmesi sonucunu tayin edecek bir takım nedenlerin devreye sokulması söz konudur (Berkes, Tarihsiz: 511-12).

18 Berkes'e göre, "Alman genelkurmayının, üç büyük rakibe karşı hazırlad1ğ 1 iki büyük projesi vardı; biri, Türk ve Arap dünyası içinden ilerleyip İngilizlerin Hindistan egemenliğine, Fransız ve İngilizlerin Yakın ve Uzak Doğu ticaret üstünlügüne son vermek; diğeri, Berlin-Bağdat yoluna eş olacak Berlin-Buhara çizgisi üzerinden hem Rusya'ya, hem Hindistan'daki İngiltere'ye kesin darbeyi indirmekti. İslamcılık birinci projenin, Turancılık da ikinci projenin aracı oldu" (Berkes, 1975b: 76). 
Bu faktörlerden birincisi, Türk toplumunun gelenekçi karakterinden uzaklaşmasıdır. İkincisi, toplumun yeni kuşaklarını bu yörüngenin gereklerine göre yetiştirmektir ki, Cumhuriyet devrimlerinin amacı, bunun gerçekleşmesinin alt yapısını oluşturmaktır. Cumhuriyet devrimleri tarihsel zorunlulukların bir sonucu olarak sadece sosyal alanlara ilişkin düzenlemeleri değil, aynı zamanda politik düzenlemeleri de gerçekleştirecek adımları atmak durumunda olmuştur. Bu kapsamda Saltanat-Hilafet sisteminin yerine Ulus sistemine geçilmiştir. Saltanat-Hilafet sisteminin yürürlükten kaldırılması bir rejim değişikliğini gerçekleştirmek anlamına gelir ki, bu, Cumhuriyeti önceki dönemlerden ayıran ve onu devrimci kılan en önemli yönüdür. Atatürk, 1924 nutuklarında toplumsal alanda yapacağı değişikliklere ilişkin temel çerçeve hakkında açıklamalar yapmıştı. Örneğin, savaş sonuçlandı fakat asıl bağımsızlık savaşı yeni başlamaktadır. Bu savaş toptan çă̆daş uygarlığa katılma savaşıdır... Bu çağda hiçbir ulus geleneksel bağlılıklarıyla varlığını sürdüremeyeceğini, eskiye ait düşüncelerin zihinler üzerinde oluşturmuş olduğu inançları söküp atmanın zorunluluklarına işaret etmiştir (Berkes, Tarihsiz: 513-14).

Atatürk'e göre, geriliklerinde direnen toplumlar, sömürülmeye mahkûmdurlar. Batı emperyalizmine karşı güçlü olmanın mümkün yolu, kendilerini uygarlık dışında bırakan bağlantılarını koparmaktır. Böylece Cumhuriyet devrimlerinin asıl yönü, toplumun kutsal saydığı ve maneviyat olarak nitelediği alanı değiştirmiş olmasıdır. Bu durumda Cumhuriyet öncesinde dinin, hayatın bütün yenlerini belirlen niteliği değiştirilerek, sosyal, kültürel ve politik hayatı modern esaslar üzerinden yeniden inşa faaliyetine girişilmiştir (Berkes, Tarihsiz: 515-16).

\section{Cumhuriyet Devrimlerinden Sapmalar}

Berkes, Cumhuriyet döneminde düşünülen ve uygulamaya konulan söz konusu değişim projelerinin giderek, Kemalizm'in bir ideolojiye dönüştürülmesine bağlı olarak amaçlarından saptırıldığına işaret etmektedir. Berkes'e göre, aslında Kemalizm bir ideoloji olmaktan ziyade, tarihsel bir olay ve iki yüz yıllık modernleşme sürecinin doğru mecrasını bulmasıdır (Berkes, 1975b: 94). Kemalizm, Türkiye' nin modern dünyada aldığı yeri ve yönü, 
devletçi politikaları ise toplumun bu amaçlara göre kalkınmasının anayasal ve hukuksal temelini oluşturmaktadır (Berkes, 1975b: 138). Yani Kemalizm bir ideoloji olmaktan ziyade Cumhuriyet Türkiyesi'nin kurucu ilkesidir (Berkes, 1975b: 137). Bu durumda Kemalizm'den ve onun temel politikası olan devletçilikten sapmak anayasadan sapmak ve dolayısıyla onun ihmali anlamina gelmektedir. (Berkes, 1975b: 138).

Kemalizm'in talihsizliği, devrimci düşüncenin toplumsal zeminden yoksun olması, toplumun ileri bir uygarlığa geçmeyi mümkün kılabilecek bir zihniyetten mahrum olması nedeniyle, devrimlerin daha çok yazı, kıyafet, takvim, kanun gibi araçlarla ön plana çıkması ve tanınması olmuştur. Dolayısıyla araçlar amaç haline gelerek, değişimin sürekliliğini mümkün kılacak olan dinamikler statik bir hale dönüşmüştür (Berkes, 1975b: 93). Serbest Fırka deneyimi, Halk Partisinin toplumun çıkarlarından uzaklaşarak devrimci düşünceden saptığını ve bir parti çıkarlarına yöneldiğinin göstergesi olmuştur. Böylece Kemalizm dondurularak totaliter bir ideoloji haline getirilerek milli şeflik doktrinine dönüştürülmüştür. Ayrıca Atatürk'ün aşkın/transaldantal bir konumda tartışılmaz bir hale getirilmesi, değişim programının uygulamalardaki normal görülebilecek hatalarının düzeltilmesine imkân tanımayan bir çerçeveye dönüşmesine neden olmuştur (Berkes, 1975b: 117-18).

Örneğin, toprak reformunun yapılamaması ve bunu devletçilik programının dışında tutulması, ekonomik açıdan köylünün kalkınmasına katkı sağlayacak tarım reformunun gerçekleştirilememesi Kemalizm'in devletçi görüşünün başarısızlığının en önemli nedenleri arasında görülmektedir (Berkes, 1975b: 127). Dolayısıyla imtiyazsız sınıfsiz bir toplum olma tezi bir iddia olarak kalmış, köy-kent arasında giderek derinleşin bir uçurum oluşmuştur. Ayrıca köylü, Devlet ve aydınların yanında ekonomik ve toplumsal açıdan bir parya haline gelmiştir (Berkes, 1975b: 133). Bu yöndeki başarısızlık sanayileşme hamleleri için de geçerlidir. Dolayısıyla tarım ve sanayiyi kapsayan bir planlamanın yürürlüğe konamaması, hedeflenen değişim ve gelişmelerin plansız ve tesadüflere bağlı olarak yapılmasına neden olmuştur. Bu durumda toplumsal 
değişim yönündeki uygulamalar ekonomik kalkınmaya nispetle ön plana çıkmıştır (Berkes, 1975b: 128). Yine Berkes'e göre, eğitimde yapılan reformalar, kalkınma planının olmaması nedeniyle beklenen neticeyi verememiştir. Çünkü eğitime ilişkin yapılan yenilik ve reformlar kalkınma hedeflerine aykırı bir şekilde gelişti (Berkes, 1975b: 129).

Dolayısıyla Cumhuriyet döneminin devletçi stratejisine bağlı kalkınma hamleleri çok kısa sürmüştür. Bunun başlıca nedenleri ise, gericilik olgusu, emperyalizmin yol açtı̆̆ 1 zararlar ve toplumun yoksullaştırılmamasıdır (Berkes, 1975b: 139). Ayrıca Halk Partisinin gerici güçlerden de aldığı destek nedeniyle Kemalist doktrini muhafaza edememesi, diğer önemli bir neden olarak görülebilir. Dolayısıyla da parti zamanla bu çıkar odaklarının etkisi altında kalması nedeniyle doktrinin ilkelerinden sapmalar meydana gelmiştir (Berkes, 1975b: 140). Böylece Bir taraftan Halk Partisi diğer yandan Demokrat Parti, Kemalist devrimleri dejenere ederek Kurtuluş Savaşının değerlerinden giderek uzaklaşan bir politik sürece girdiler (Berkes, 1997:7). Bütün bu gelişmeler özellikle ikinci dünya savaşı sonunda, ortaçağ kalıntısı geleneklerin etkisinin sürmesine bağlı olarak eski-yeni ${ }^{19}$ ayrımını keskinleştirerek toplumsal çatışmalara neden olmuştur. Berkes'e göre Demokrat Parti ideolojisi, gerici güçleri temsil eden ve dolayısıyla Cumhuriyetin kurucu ilkesinden sapmaya ve toplumda giderek büyüyecek olan kutuplaşmaya neden olan diğer bir unsurdur (Berkes, 1975b: 138). Bütün bunlara bağlı olarak Kemalizm'in Türkiye'nin bağımsız bir ulus olarak kendi kaynaklarına bağlı kalkınma, değişim ve gelişme idealleri toplumsal kesimden destek bulamad ${ }^{20}$ (Berkes,

19Berkes'in eksi-yeni kavramsallaştırması ile Mardin'in çevre-merkez kavramsallaştırması arasında bir benzerlik kurabiliriz. Berkes'te yeni, Cumhuriyet döneminde biçimlenen siyasal eliti yani merkezi temsil ederken $\boldsymbol{e s} \boldsymbol{k} \boldsymbol{i}$; merkezin dışındaki geleneksel toplum tabakasını oluşturan çevredir.

20 Berkes, bütün bu gelişmelerin genel bir değerlendirmesini yaparken, diğer faktörlerin yanında temelde toplumsal zihin dünyasının hala geleneksel düşünceden tam olarak kopamayan ve dolaysıyla gerici unsurların etkisine bağlamaktadır. "Çünkü o zaman Türk toplumu henüz daha bir ulus birimi değildi. O zaman henüz daha bu birimin Kemalizm ilkelerinde toplanan yasa-yapısı yoktu. İslam dini, henüz devletin resmi dini idi" (Berkes, 
1975b: 140). Dolayısıyla, gerici güçlerin Kemalist devrimleri sulandırması sonucunda, Türkiye'nin iki yüzyıllık modernleşme çabalarından sonra gelişmemiş toplumların durumuna düşürülmesinin nedenini başka bir yerde aramaya gerek yoktur (Berkes, 1975b: 171).

\section{Sonuç}

Tanzimat döneminden başlayarak günümüze kadar yaşanan değişimlere ve bu çerçevedeki süreçlere yönelik, tarihsel, politik, ekonomik ve sosyolojik olarak farklı disiplinler bağlamında birçok değerlendirme yapılmıştır. Bizim burada ele aldığımız metin, özellikle sosyoloji bağlamında Berkes' in söz konusu süreçlere ilişkin yaptığ değerlendirmeleri içermektedir. Türk modernleşme süreçlerini örneğin Şerif Mardin merkez-çevre kavramsallaştırmasına; Baykan Sezer Doğu-Batı ayrımına dayanarak çözümlemeye çalışırken Berkes, sekülerleşme kavramına müracaat etmektedir. Berkes bu çerçevede ilericilik, gericilik ve kutsallaştırılmış gelenekler gibi kavram kategorileriyle modernleşme olgusunu Türk toplumu üzerinden değerlendirmiştir.

Berkes, Osmanlının Batı karşısındaki giderek zayıflamaya başlamasına bağlı olarak, bu durumu düzeltmek ve eski gücüne tekrar kavuşmak maksadıyla, Tanzimat ve Meşrutiyet dönemlerinde alınmış olan bir dizi önlemlerin, sorunların çözümünde kalıcı bir katkı sağlayamadığını iddia etmiştir. Bunun nedeni olarak da, tüm değişim çabalarına rağmen toplumsal yapıdaki kutsallaştırılmış geleneksel kodların devam etmesi ve bunlara rağmen alınan reform içerikli önemlerin etkili olamayacağı göstermiştir. Ayrıca Berkes, Osmanlıyı, politik bir yapı olarak doğu despotizmini temsil etmekte olduğu tezi üzerinden değerlendirmiştir.

Doğu despotizmi, Montesquieu, Marx, Karl Wittfogel ve daha birçok Batılı sosyal bilimci tarafından kavramsallaştırılarak doğu toplumlarının sosyo-politik yapılarının bir analiz aracı olarak kullanılmıştır. Devletin keyfi tutumu ve toplum üzerindeki mutlak otoritesinin söz konusu olduğu bu yaklaşım, Avrupamerkezci

1975b: 142). 
bir perspektifin ürünü olup, analitik niteliği son derece zayıftır. Fakat Türk sosyal bilimcilerinin bir kısmı, bu kavrama gereğinden fazla anlam atfetmiş olduklarını söyleyebiliriz. Berkes de Osmanlı toplumuna ilişkin değerlendirmelerinde merkezi bir kavram olarak kullanmıştır. Modern toplum düzenine geçişi tarihsel bir zorunluluk olarak niteleyen Berkes, bu iddiasını modern tarih yazımına dayandırmaktaydı. Dolayısıyla tarihin evrimci yasalarına bağlı olarak toplumlar Despotizmden demokrasiye doğru evrilmek gibi bir seyir takip etmektedir. Berkes, temel yaklaşımını sosyal bilimlerin verilerine bağlı olarak belirlediğini ve Osmanlı toplumuna ve değişim süreçlerine açıklamaya yönelik analizlerini de bu çerçevede yaptığını iddia etmiştir. Fakat günümüzde sosyal bilimler ve ortaya koymuş oldukları evrenselci iddiaların, esasında Avrupamerkezci bir tecrübe üzerinden bir dünya tarihi okumasına dayandığı yönünde ciddi eleştiriler ortaya konmuştur. $\mathrm{Bu}$ açıdan yorumlandığında Berkes'in yorumlarının Pozitivist, Avrupamerkezci bilim paradigmasına dayalı olarak yapıldığını söyleyebiliriz. Bu tür yaklaşımların bilimsellik değerine yönelik günümüze dek yapılan önemli eleştiriler ve oluşmuş bir literatür mevcuttur. 


\section{Kaynaklar}

Berkes, Niyazi, Türk İktisat Tarihi, 2. Cilt, Gerçek Yayınları, 2. Bask1, İstanbul,1975a.

, Türk Düşününde Batı Sorunu, Bilgi Yayınevi, İstanbul, 1975b.

., Türk İktisat Tarihi, 1. Cilt, Gerçek Yayınları, 3. Baskı, İstanbul,1976.

, Batıcılık, Ulusçuluk v e Toplumsal Devrimler 1, Cumhuriyet Gazetesi, Yayınları, İstanbul, 1997.

Felsefe ve Toplumbilim Yazıları, Adam Yayınları, İstanbul, 1985.

Atatürk ve Devrimler, Adam Yayınları, İstanbul, 1993.

Doğan, Atila, Osmanlı Aydınları ve Sosyal Darvinizm, İstanbul Bilgi Üniversitesi Yayınları, 2006.

Hanioğlu, Şürkü, Bir Siyasal Düşünür Olarak Abdullah Cevdet ve Dönemi, Üçdal Yayınları, İstanbul, 1986.

Kaçmazoğlu, H. Bayram, Türk Sosyolojisinde Temalar 2-Kuram Uygulama Sosyalizm, Doğu Kitabevi, İstanbul, 2012.

Kayalı, Kurtuluş, Türk Düşünce Dünyasında Yol İzleri, İletişim Yayınları, İstanbul, 2011.

Özlem, Doğan, Siyaset, Bilim ve Tarih Bilinci, İnkılap Yayınları, İstanbul, 1999.

Yıldırım, Hayali Modernlik -Türk Modernliğinin İcad1-, Doğu Kitabevi, İstanbul, 2012. 